\title{
Gender Differences in Police Stress, Coping, and Burnout in India
}

\author{
Priya Xavier
}

\begin{abstract}
There has been numerous studies carried on among police officers and stress with contradictory results. Specifically, demographic factors have been studied as an intervening variable among stress and burnout. But still, further studies are needed to establish the relationship of demographic factors with police stress. The current study aims to find differences in police stress, coping, burnout and moral reasoning among police officers in Tamil Nadu. Using the T test we found that there is no difference in stress experienced by male and female officers. Similarly, there is no difference in moral reasoning levels of male and female officers. Differences were found in burnout and coping styles used by male and female officers. This shows that male and female officers cope differently to stressful situations and so experience burnout differentially.
\end{abstract}

Index Terms: About four key words or phrases in alphabetical order, separated by commas.

\section{INTRODUCTION}

Job stress is a concern for many occupational groups, some professions appear to be more vulnerable to experiencing high levels of stress at work than others (Kop, Euwema \& Schaufeli,1999). Policing is a high stress occupation with police officers reporting high levels of stress and burnout.

The Indian police were designed following a colonial model by British rulers in 1861. Many developments can be seen post -independence and policing profession has seen the inclusion of female officers as the years passed. In Tamil Nadu police force women have risen to the post of DGP, Director General of Police the highest rank in police hierarchy with Kiran Bedi being the first female officer as DGP of police. With the rise in crime, law and order issues more studies have been undertaken in order to strengthen the police force. Some of the problems inherent in policing like stress and burnout have been studied in different states in India. The gender - specific issues in policing have not been addressed extensively in India.

In the study by Merry Morash, Dae-Hoon Kwak \& Robin Haarr, (2006), it was confirmed that problems encountered at workplace account for a substantial amount of police officer's stress regardless of social support, community/organizational conditions and demographic factors. It was noted that for both male and female officers, profanity and sexual jokes were related to stress. In the Indian context, we find gender segregation prominent in policing with all women police stations available in some locations. In major locations when men and women officers work together, there is a culture of

Revised Manuscript Received on July 05, 2019.

Dr. Priya Xavier, Faculty of Management, SRM Institute of Science \& Technology, Kattankulathur -603203, India. male dominance prevalent as part of the Indian cultural belief system. So we have attempted to see the difference in stress, burnout, moral reasoning and coping among men and women police officers.

Continuous exposure to traumatic events leads to sleep disturbances, irritability, marital problems, and alcohol abuse. Our modern society, with its ever- increasing charges of police brutality, corruption, gang crimes and the deteriorating ethical and moral values demand that law enforcement officers be psychologically and physically fit. A better knowledge of the sources of stress among police officers, its deleterious effect due to maladaptive coping mechanisms is essential in order to maintain psychologically and physically healthy law enforcement machinery. Future research is needed to find out gender differences among law enforcement professionals' experience of stress and coping .

This study tries to bring the differences in police stress, coping, moral reasoning and burnout experienced by male and female officers in Tamil Nadu, the southern state of India. The article presents a literature review followed by methodology. The results are found analyzing the data collected among 296 police officers in Tamil Nadu. The discussion follows on the differences found among the officers with the concluding note

\section{LITERATURE REVIEW}

On the basis of gender, senior male and female police officers use different coping strategies.

Studies reveal that Male officers' perceive that one of the important predictor of their stress is their lack of influence over practices and procedures at work. While the studies do not clearly indicate this as a predictor of stress for women police officers. The research carried on by Don L. Kurtz (2008) indicated stress and burnout by officers are embedded in the gender structure and process of policing and not simply a response to high stress events.

As far as gender is concerned Kirk- Brown et al. (1999) argued that female officers lack social support compared to their male officers due to their minority status and overall masculine nature of police work.

Cherniss identified five sources of stress as antecedents of burnout. These included: doubts about one's competence, problems with clients, bureaucratic interference, lack of stimulation and fulfillment and lack of collegiality. Cherniss (1980) divides the various types of intervention in the workplace that can be used to reduce burnout into four categories: staff development and counseling, the structure of the job, leadership and supervision and organizational goals, methods, and norms. 
The objective of the study is to find the differences in police stress, coping, moral reasoning and burnout among male and female police officers in Tamil Nadu.

\section{Data \& Descriptive Statistics}

The respondents were police officers both male and female belonging to the Tamil Nadu police from sub inspectors rank and above, India who were in active service with experience ranging from 4 yrs to 25 yrs.

A total of 1000 questionnaires were given to respondents using convenience sampling.We could take only 296 questionnaires for analysis due to data inconsistency.

Once the data were collected and checked for completeness, the data were coded and entered in excel sheet for statistical analysis.

$90 \%$ of respondents were male officers and $10 \%$ of respondents were female officers. There were 29 female officers and 267 male officers.

\section{Methods}

Subjects were informed through a cover letter of the purpose of the study and that participation was voluntary and that the questionnaires were strictly for research purpose. They were also told that the information provided would be kept confidential. The subjects were advised that it would take approximately 75 minutes to complete all the questions. Measures

As the current study is part of the doctoral work undertaken by the author in which the instruments used were PSS, MBI, CRI and DIT2, the same instruments are highlighted in the present study.

Police Stress Survey

This instrument was used for collecting data regarding the police stress in this study.

Charles D. Spielberger, Lynne G. Westberry, Kenneth S. Grier, and Gloria Greenfield developed the instrument in 1981 as part of the research conducted by them called the Florida Police Stress Project (FPSP). PSS has also been used in "Profiling those impacted by organizational stressors at the macro, intermediate and micro levels of several police agencies" by Deborah L. Laufersweiler- Dwyer and R. Gregg Dwyer (2000) in The Justice Professional, Vol.12. Pp.443-469.

DIT2 is a scale used to measure the moral reasoning level. It has five social dilemmas with twelve considerations related to each social dilemma which comprise of issues which lead to identifying in which level of moral reasoning a respondent is.

\section{RESULTS}

H1: There is a significant difference between gender and police stress, burnout, coping style, and moral reasoning.

We find that male and female officers show a difference in various dimensions of burnout and coping reflected in mean difference in emotional exhaustion, depersonalization, reduced personal accomplishment and coping mechanisms.

Female officers exhibit more emotional exhaustion compared to male officers. This might be due to the nature of the work assigned to them. Male officers are more depersonalized compared to female officers. This indicates the differences in stressful events encountered by these police officers. The female officers experience more personal accomplishment compared to male officers.

It is interesting to see that the overall burnout score does not show a significant difference between male and female officers.

Coping mechanisms used by officers show significant differences among male and female officers. Male officers scored 46.49 while female officers scored 51.82 on Positive Reappraisal. This shows that women police were using more of problem- focused coping mechanism. In seeking guidance mechanism, female officers were 55 while male officers were 49.09. So female officers used this mechanism while encountering a stressful situation. They obtained help from superiors, peers and family members. It is surprising to see that female officer used more of Cognitive avoidance compared to male officers. This avoidance coping style was used more by female officers in order to avoid thinking realistically about a problem.

Female officers quickly accept or resign to the problem by accepting it. Seeking alternative rewards style of coping is used more by female officers, compared to male officers. This shows that if the case isn't rewarding female officers try to choose alternative sources of rewards.

Finally, female officers use more of emotional discharge 64.23 , compared to male officers 54.75 while at work. This shows that they are using the avoidance coping mechanism by reacting negatively and expressing negative thoughts and shouting at the offenders. CRI Adult Form Manual has been used to score the CRI.

\section{DISCUSSION}

We infer from the results that male and female officers are experiencing burnout at different levels and their coping mechanisms are different.

Female police officers are found to be more emotionally exhausted compared to male police officers. This may be due to the stressors inherent in the role of police officer, nature of police organization and personal life. Female officers are much more depersonalized in comparison with male officers. This shows that female officers are more cynical compared to male officers. Johnson (1991) found that female officers exhibited higher levels of emotional exhaustion. Current research findings support this study.

Female officers do not find sufficient satisfaction by solving cases and so are experiencing lower personal accomplishment. This may be due to lower recognition of female officers achievement by the police organization. While considering coping mechanisms used by the officers, female officers are using two approach coping mechanisms which are positive reappraisal and seeking guidance \& support. Female officers are using avoidance coping mechanisms like cognitive avoidance, acceptance or resignation, seeking alternative rewards and emotional discharge. There is a difference among male and female officers in the use of the above mentioned coping responses. We see from the results that

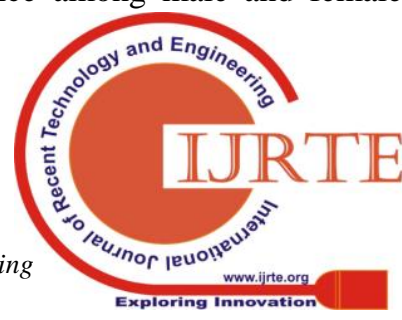


female officers are using more of these coping mechanisms compared to male officers. The reason may be that the female officers are still younger compared to male officers in the current study as 194 respondents from the police training academy respondents used in the research are senior male police officers. They are using avoidance coping as they are not aware of better coping mechanisms in approach coping. As far as gender is concerned Kirk- Brown et al. (1999) argued that female officers lack social support compared to their male officers due to their minority status and overall masculine nature of police work. This supports the research finding of the use of avoidance coping mechanisms by the female Indian police officers.

Since the results show no significant difference in police stress experienced by male and female officers, both officers are stressed to the same extent. But while coping with the stressors female officers are not able to cope effectively and which is leading to their feeling more burn out.

There is no difference as far as moral reasoning is concerned among male and female officers. So the male and female officers seem to be in the maintaining norms stage of moral reasoning in which they adhere to the rules and regulations of the police organization. They do not have higher levels of moral reasoning as the mean values indicated

\section{CONCLUSION}

There is a difference between male and female police officers as far as burnout and coping styles are concerned. Taking cognizance of the less number of female officers in the study, we can infer that female officers have not had the opportunity to make use of more approach coping mechanisms. The number of female officers has to be increased in future studies. Female officers taken for the study show more use of both approach and avoidance coping as shown in the past literature, compared to their male counterparts. This shows that female officers due to the very nature of police work are more prone to emotion based coping strategies which are leading them to burnout, rather than using a more problem based mechanism of coping.

\section{REFERENCES}

[1] Amirkhan, JH., (1990). A factor analytically derived measure of coping: The Coping Strategy Indicator. Journal of Personality and Social Psychology. 59, 1066-1074.

[2] Anderson, G., Litzenberger, R., \& Plecas, D. (2002). Physical evidence of police officer stress. Policing: An International Journal of Police Strategies \& Management, 25, 399-420.

[3] Barker - Collo, S.L. (2001). Relationship of the Dissociative Experiences Scale to demographics, symptomatology, and coping strategies in a New Zealand student sample. Journal of Trauma and Dissociation, 2 (3), 81-101.

[4] Berg, A. M., Hem, E., Lau, B., Loeb, M., \& Ekeberg, O. (2003). Suicidal ideation and attempts in Norwegian police. Suicide and Life Threatening Behavior, 33, 302-312.

[5] Bogdonoff, D.A. (2002). Resilience as a predictor of abstinence in the recovery from alcohol dependence (Doctoral dissertation, California School of Professional Psychology and Alliant 4361B.

[6] Brooks, L. W., \& Piquero, N. L. (1998). Police stress: Does department size matter. Policing: An International Journal of Police Strategies \& Management, 21, 600-617. in the result. International University). Dissertation Abstracts International, 63

[7] Brown, J. and Campbell, E.A. (1994). Stress and Policing, John Wiley, Chichester.

[8] Brown, J. M., \& Fielding, J. (1993). Qualitative difference in men and women police officers' experience of occupational stress. Work and Stress, 7, 327-340.

[9] Bruce Kirkcaldy, Jennifer Brown \& Cary L. Cooper, (1998). The demographics of occupational stress among police superintendents. Journal of Managerial Psychology, 13(1),90-101.

[10] Burke, R. J. (1994). Stressful events, work-family conflict, coping, psychological burnout, and well being among police officers. Psychological Reports, 75, 787-800.

[11] Burke, R. J., \& Mikkelsen, A. (2005). Gender differences in policing: Signs of progress. Employee Relations, 27, 425-436.

[12] Cherniss, C. (1980). Professional burnout in human service organizations. New York: Praeger.

[13] Collins PA \& Gibbs AC. (2003). Stress in police officers: A study of the origins, prevalence and severity of stress related symptoms within a county police force. Occupational Medicine, 53 (4) ,256-64.

[14] Cooper, M.L., Frone, M.R., Russell, M., \& Peirce, R.S. (1997) Gender, stress, coping, and alcohol use. In R.W. Wilsnack \& S.C. Wilsnack (Eds.), Gender and alcohol: Individual and social perspectives (pp. 199-224). Piscataway, NJ: Rutgers University Press.

[15] Dinesh Nagar (2009).A study of occupational stress and health in police personnel. The Indian Police Journal, LVI- No. 4, 47-54.

[16] Don L. Kurtz. (2008). Controlled Burn: The Gendering of Stress and Burnout in Modern Policing. Feminist Criminology, 3,216, DOI: $10.1177 / 1557085108321672$.

[17] Don Ivie \& Brett Garland, (2011).Stress and burnout in policing: does military experience matter? Policing: An Internationa Journal of Police Strategies \& Management, 34 ( 1), 49 - 66.

[18] Ellison, K.W. and Genz, J. (1983), Stress and the Police Officer, Thomas, Springfield, IL.

[19] Garcia, V. (2003). "Difference" in the police department: Women, policing, and “doing gender." Journal of Contemporary Criminal Justice, 19, 330-344.

[20] Goolkasian, G.A., Geddes, R.W. and DeJong, W. (1985), Coping with Police Stress, Government Printing Office, Washington, DC.

[21] Green B. (2004). Post -Traumatic Stress Disorder in UK Police Officers. Curr Med Res Opin. , 20 ( 1) ,101-5

[22] Griffith, M. A., Dubow, E.F., \& Ippolito, M. F. (2000) Developmental and cross-situational differences in adolescents' coping strategies. Journal of Youth and Adolescence, 29 (2), 183-204.

[23] Haarr, R.N. and Morash, M. (1999).Gender, race, and strategies of coping with occupational

[24] stress in policing. Justice Quarterly, 16 (2), 303-36.

[25] Hamberger LK, Lohr JM, Bonge D \& Tolin DF. (1997). An empirical classification of motivations for domestic violence. Violence Against Women, 3,401-423.

[26] Hawkins, H.C. (2001).Police officer burnout: a partial replication of Maslach's burnout

[27] Inventory. Police Quarterly, 4 (3), 343-60.

[28] He, N., Zhao, J. \& Archbold, C.A. (2002). Gender and police stress: the convergent and

[29] divergent impact of work environment, work-family conflict, and stress coping mechanisms of female and male police officers. Policing: An International Journal of Police Strategies \& Management, 24 (4), 687-708.

[30] Hochschild, A.R. (1983). The Managed Heart: The Commercialization of Human Feeling, University of California Press, Berkeley, CA.

[31] Jennifer Brown, Jane Fielding \& Jennifer Grover. (1999). Distinguishing traumatic, vicarious and routine operational stressor exposure and attendant adverse consequences in a sample of police officers. Work \& Stress, 13 (4), 312-325.

[32] Johnson, L.B. (1991). Jobstrain among police officers: gender comparison , Police Studies, 14, 12-16.

[33] Julia Scott, Doug Evans \& Arvind Verma. (2009).Does higher education affect perceptions among police personnel? A response from India. Journal of Contemporary Criminal Justice, 25 (2), 214-236.

[34] Kao, Y.T. (2000). A study of Taiwanese adolescent 
stress: Stress sources, coping skills, and social supports (Doctoral dissertation, Indiana University, 2000). Dissertation Abstracts International, 60, 3921A

[35] Kohn, C.S., Mertens, J.R., \& Weisner, C.M. (2002). Coping among individuals seeking private chemical dependence treatment: Gender differences and impact on length of stay in treatment. Alcoholism: Clinical and Experimental Research, 26 (8), 1228-1233.

[36] Kop, N., Euwema, M., \& Schaufeli, W. (1999). Burnout, job stress, and violent behaviour among Dutch police officers. Work and Stress, 13 ( 4), 326-340.

[37] Kirk-Brown, A., Thompson, B.M. and Brown, D.F. (1999). "The relationship between work stressors, social support, and emotional exhaustion in female employees of the Queensland Police Service”, paper presented at the 3rd Australian Industrial and Organizational Psychology Conference, Brisbane, Australia.

[38] Kroes, W.H. (1982). Job stress in policewomen; an empirical study, Police Stress, Winter, pp. 10-11.

[39] Levenson RL Jr \& Dwyner LA. (2003). Peer Support in law enforcement: Past, Present and future. International journal of emerging mental health, 5 ( 3 ) ,147-52.

[40] Liberman, A. M., Best, S. R., Metzler, T. J., Fagan, J. A., Weiss, D. S., \& Marmar, C. R. (2002). Routine occupational stress and psychological distress in police. Policing: An International Journal of Police Strategies \& Management, 25, 421-439.

[41] Lonsway, K., Carrington, S., Moore, M., Harrington, P., Smeal, E., \& Spillar, K. (2002). Equality denied: The status of women in policing - 2001. Beverly Hills, CA: National Center for Women and Policing.

[42] Loo, R. (2004). A typology of burnout types among police managers. Policing: An International Journal of Police Strategies \& Management, 27, 156-165.

[43] Mashburn, M. D. (1993). Critical incident counseling. FBI Law Enforcement Bulletin, 62(9), 5-9.

[44] Merry Morash, Dae-Hoon Kwak \& Robin Haarr, (2006).Gender differences in the predictors of police stress. Policing: An International Journal of Police Strategies \& Management, 29 (3), $541-563$

[45] Michinov, N. (2005). Social comparison, perceived control, and occupational burnout. Applied Psychology: An International Review, 54, 99-118.

[46] Mikkelsen, A., \& Burke, R. J. (2004). Work-family concerns of Norwegian police officers: Antecedents and consequences. International Journal of Stress Management, 11, 429-444.

[47] Moos RH \& Holahan CJ.(2003) Dispositional and contextual perspectives on coping: Toward an integrative framework. Journal of Clinical Psychology, 59,1387-1403.

[48] Morash, M. and Haarr, R.N. (1995).Gender, workplace problems, and stress in policing. Justice Quarterly, 12 ( 1), 113-40.

[49] Newman, D. W., \& Rucker-Reed, M. L. (2004). Police stress, state trait anxiety, and stressors among U.S. marshals. Journal of Criminal Justice, 32, 631-641.

[50] Noblet, A.J., Rodwell, J.J. \& Allisey, A.F. (2009). Police stress: the role of the psychological contract and perceptions of fairness. Policing: An International Journal of Police Strategies \& Management, 32 (4), $613-630$.

[51] Norvell, N.K., Hills, H.A. and Murrin, M.R. (1993).Understanding stress in female and male law enforcement officers. Psychology of Women Quarterly, 17 ( 3), 289-301.

[52] Patterson, K.T.(2001). The effect of gender on a predictive model of violent behaviors in rural youth using a contextual framework (Doctoral dissertation, University of Pittsburgh, 2001). Dissertation Abstracts International, 62, 2259B.

[53] Purpura, P. (2001). Police and community. Boston: Allyn \& Bacon.

[54] Ronald J. Burke, (1987).Burnout in Police work: An examination of the Cherniss model. Group \& Organization Studies, 12 (2) , 174-188

[55] Sharma, K. (2007, July 29). Be safe: Don’t exist. The Hindu.

[56] Sibnath Deb, Tanusree Chakraborty, Pooja Chatterjee \& Neerajakshi Srivastava, (2005). Psychological stress of Traffic Police officers, causal factors behind the same and their Coping Strategies. The Indian Police Journal, LII (3),16-30

[57] Snow, DL, Sullivan, TP, Swan, SC, Tate, DC \& Klein I.(2006) The role of coping and problem drinking in men's abuse of female partners: Test of a path model. Violence and Victims, 21,267-285
[58] Sonia Udod, Greta G. Cummings, W. Dean Care \& Megan Jenkins. (2017). Role stressors and coping strategies among nurse managers. Leadership in Health Services, 30 (1), pp.29-43, https://doi.org/10.1108/LHS-04-2016-0015

[59] Spielberger, C., Westberry, L., Grier, K., \& Greenfield, G. (1981). The police stress survey: Sources of stress in law enforcement. Tampa, FL: Human Resources Institute.

[60] Swan, SC \& Snow, DL. (2006). The development of a theory of women's use of violence in intimate relationships. Violence Against Women, 12,1026-1045.

[61] Thomas, A.H. (1998). The relationship of prevention training and violence exposure to psychological trauma, coping skills, and attitudes toward violence for urban African -American adolescents (Doctoral dissertation, Howard University, 1998) Dissertation Abstracts International, 58, 4475B.

[62] Umesh Kumar Singh (2005).Feudalization of ancient Indian police organization (300 A.D. to 750 A.D.). The Indian police journal, LII No. 2, 21-40.

[63] Verma, A. (2005).The Indian police: A critical evaluation. New Delhi: Regency Publications.

[64] Violanti JM \& Gehrke A. (2004). Police trauma encounters Precursors of compassion fatigue. International journal of emerging mental health,6 (2) ,75-80.

[65] Wegerle, G.L. (1997). Problem- focused (approach) and emotion - focused (avoidance) stress coping strategies utilized by United States Air Force personnel. (Doctoral dissertation, University of Kansas, 1997). Dissertation Abstracts International, 58, 1581B.

[66] Wexler, J.G. and Logan, D.D. (1983).Sources of stress among women police officers. Journal of Police Science and Administration, 11 ( 1), 46-53.

[67] Zanini, D.S. Coping:Influence of personality and repercussions on the adolescents' mental health. Doctoral dissertation, University of Barcelona, Spain,2003. 